\title{
Securities Loans Collateralized by Cash: Reinvestment Risk, Run Risk, and Incentive Issues
}

\author{
Frank M. Keane
}

Securities loans collateralized by cash are by far the most popular form of securities-lending transaction. But when the cash collateral associated with these transactions is actively reinvested by a lender's agent, potential risks emerge. This study argues that the standard compensation scheme for securities-lending agents, which typically provides for agents to share in gains but not losses, creates incentives for them to take excessive risk. It also highlights the need for greater scrutiny and understanding of cash reinvestment practicesespecially in light of the AIG experience, which showed that risks related to cash reinvestment, by even a single participant, could have destabilizing effects.

\footnotetext{
A lthough less researched than the money markets, the collateral markets are critical to the efficiency of the asset markets-including the markets for Treasury, agency, and agency mortgage-backed securities. Well-functioning collateral markets allow dealers and investors in the asset markets to finance short positions for the purposes of hedging, market making, settlement, and arbitrage.

Two important mechanisms for accessing the U.S. money and collateral markets are repurchase agreements (repos) and securities-lending transactions. In a money market transaction, when cash and securities are exchanged, the securities act as collateral and mitigate the risks associated with a borrower's failure to repay the cash. In a collateral market transaction, however, the cash serves as collateral and mitigates the risk associated with replacing the security if the borrower fails to return it.
}

In the most common form of securities lending, the borrower offers cash as collateral for the security. But the cash in this case can play another role when it is actively reinvested by a third-party agent to enhance returns. Such cash reinvestment strategies, if aggressive enough, can result in hidden risks and raise conflicts with the role of cash as collateral.

This edition of Current Issues focuses on loans of securities collateralized by cash and the potential risks associated with the reinvestment of that cash. This reinvestment of cash often entails liquidity and maturity transformation. Liquidity transformation occurs if the time required to sell the acquired assets exceeds the maturity of the security loan transaction, while maturity transformation occurs if the maturity of the acquired assets exceeds the maturity of the security loan transaction. In both cases, fire sales and run-like behavior can result, leading to a more fragile financial system. Indeed, excessive maturity and liquidity transformation from securities lending was a feature of the recent financial crisis. 
This article also considers how the standard compensation scheme for securities-lending agents, who typically are responsible for reinvesting cash collateral, creates incentives for the agents to take excessive risk. These agents receive a portion of investment returns, but are not subject to loss sharing should the reinvestment strategies prove unprofitable. The asymmetric payoff of the standard compensation arrangement is similar to giving a call option to the agent, which, all else equal, provides the agent with an incentive to pursue high-risk investment strategies.

The analysis opens with a short overview of securities lending, followed by a look at the risks inherent in related cash reinvestment activities. The discussion then turns to the incentive problems associated with the standard compensation scheme for lending agents.

\section{Brief Overview of Securities Lending}

\section{Basic Terminology}

The term "securities lending" refers to the collateralized loan of a security from one party to another. Such a loan can have a pre-specified term, such as one business day, one week, or one month, or it can be "open." An open loan is ongoing until one of the parties to the trade decides to end it. Open trades are by far the most common.

A range of different methods can be used to collateralize the security lender's exposure. ${ }^{1}$ The most typical forms of the securities loan transaction are as follows:

Borrow versus cash. The borrower of the security offers cash as collateral to the security lender. This is the most common form of collateral for the securities loan.

Borrow versus pledge. The loan of the security is collateralized by other securities. This is the second most popular form of collateral.

Borrow versus letter of credit. A letter of credit collateralizes the loan of the security. This type of transaction is rarely used, possibly because of the up-front cost of the letter of credit and the variable size of day-to-day securities-lending activity.

Borrow program. This program takes the form of a customized term loan of a portfolio of securities. Because the transaction is customized, it is difficult to make general statements regarding its use. That said, borrowers of securities may negotiate an annual fee for rights to borrow securities from a beneficial owner's entire portfolio. ${ }^{2}$ The annual fee may represent a good bargain for the lender or the borrower, depending on how collateral market conditions evolve for the securities held in that portfolio.

\footnotetext{
${ }^{1}$ For a full discussion, see Lipson et al. (2012).

${ }^{2}$ A "beneficial owner" is an individual or group that owns and may dispose of an asset, even though that asset may be held in custody by another party such as a bank or a broker.
}

\section{Role of Agent Lender}

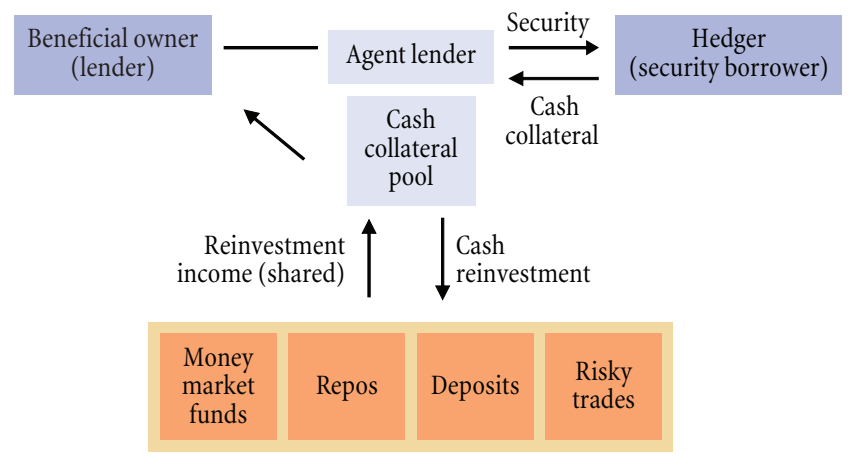

Source: Author's depiction of agent role, adapted from Beltran et al. (2013).

It is common to read about repo or securities-lending "markets," yet a more careful use of terminology would avoid this nomenclature because repo and securities loans are merely transactional forms used to access the money or collateral markets. (See Box 1 for a brief discussion of the intersection of repo and securities-lending transactions.)

\section{Market Participants}

The most common borrowers of securities are broker-dealers, hedge funds, and portfolio managers. The beneficial owners and lenders of the securities are typically mutual funds, insurance companies, pension funds, and banks. Agent lenders also play a key role in these transactions. The agent function may be performed by the custodian for the beneficial owner of the securities, by an internal business function within the beneficial owner, or by an independent entity.

As illustrated in the exhibit above, agents usually perform two important services for the beneficial owners of the securities: 1) they facilitate loans of securities into the collateral market, and 2) they invest the cash received as collateral against the lent securities. ${ }^{3}$ The cash collateral is most often invested in safe and liquid products, such as money market funds, repos, or deposits, but it can also be invested in products with substantial price risk and/or limited liquidity, such as residential mortgage-backed securities of various credit qualities.

Agent lenders commonly offer the beneficial owner some form of indemnity against losses in the event the borrower fails to return the lent security. However, such protection or indemnification of the beneficial owner does not extend to cash reinvestment activity, in which beneficial owners are fully exposed to unsuccessful investment strategies.

\footnotetext{
${ }^{3}$ From the beneficial owner's perspective, cash reinvestment represents a leverage of the owner's outright portfolio holdings. The lent security still contributes to portfolio returns, and the cash reinvestment adds additional market exposure for the duration of the securities loan.
} 
Box 1

\section{Intersection of Repo and Securities-Lending Transactions}

The institutional composition of the securities-lending and repurchase agreement (repo) markets overlaps nearly completely. That is, there are no broad classes of institutional market participants that engage only in securities lending. Users of fixed-income collateral markets predominantly use repo transactions to borrow securities in the collateral market and, to a lesser but still sizable extent, use securities loan transactions. For equity securities, participants mostly use securities lending to borrow shares.

While repo transactions always involve an exchange of cash and securities, securities-lending transactions may or may not involve an exchange of cash. Since the financial crisis in 2008, there has been some increase in the use of noncash collateral in U.S. securities-lending transactions, although securities loans collateralized by cash remain the predominant form. Available data indicate that securities loans collateralized by cash still account for more than 70 percent of overall activity (see chart).

A common distinction between repo loans and securities-for-cash loans is that repo borrowers are typically "leveraged money" investors, while beneficial owners that lend securities against cash are typically "real money" investors. Accordingly, most repo borrowers have a specific need for the cash, often taking the cash they get from the repo and "reinvesting" it in the security given as collateral in order to support a specific business need. This use allows repo borrowers to reduce the amount of capital they use to finance securities in the course of doing business. In contrast, many lenders of securities do not have a specific business need for the cash, and their reinvestment of it can be unrelated

\section{Market Size}

Data on securities lending are fragmented and cannot be found comprehensively through any one source, so it is no surprise that authorities are seeking greater transparency around this activity. ${ }^{4}$ One source that provides a partial view into the size of securities-lending transactions is Markit ${ }^{\mathrm{TM}}$ Group Limited. The private data from Markit are collected from a panel of securitieslending agents and have a fairly broad focus. They include measures of earnings in addition to data on market activity. For example, the Markit panel reported that $\$ 809$ billion of government bonds was available for lending in September 2012, of which $\$ 337$ billion was out on loan. Chart 1 displays the value of securities on loan, according to the Markit reporting panel, between September 2009 and December 2012 for three classes of securities: equities, government bonds, and corporate bonds. The values have been stable over that period. Loans of equities were comparable in size to loans of government securities, while loans of corporate securities were less than either of the other two. ${ }^{5}$

\footnotetext{
${ }^{4}$ The Financial Stability Board's “Interim Report on Repo and Securities Lending” recommends increased transparency and greater data collection going forward.

${ }^{5}$ The low relative loan volumes for corporate securities may reflect the relative lack of liquidity for corporate bond markets compared with the markets for equities and government securities.
}

to their primary business. As such, this use has the potential to include considerable hidden risk.

Many repo transactions are "direct" between borrower and lender, involving no agent. When an agent is present, there is no reinvestment of cash as is common in securities loan markets. Tri-party repo transactions, which constitute a large fraction of repo trading, use clearing banks as agents to manage operational costs associated with pledging, valuing, and optimally allocating collateral between borrowers and investors. Services of a clearing bank are based on fees rather than a fraction of reinvestment returns. Accordingly, the incentive issues present with securities-lending agent compensation are avoided.

\section{Securities-Lending Transactions: Cash versus Noncash Collateral}

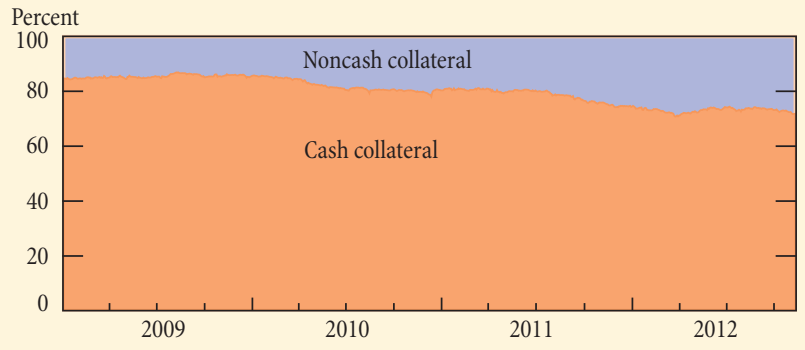

Source: Markit ${ }^{\mathrm{TM}}$ Group Limited.

Transaction Revenue Components and the Rebate Rate For collateral market participants, there are two potential sources of earnings from the form of securities lending that uses cash collateral: intrinsic value and reinvestment return. The intrinsic value equals the fee paid by the borrower of the security. Perhaps

Chart

\section{Value of U.S. Securities on Loan}

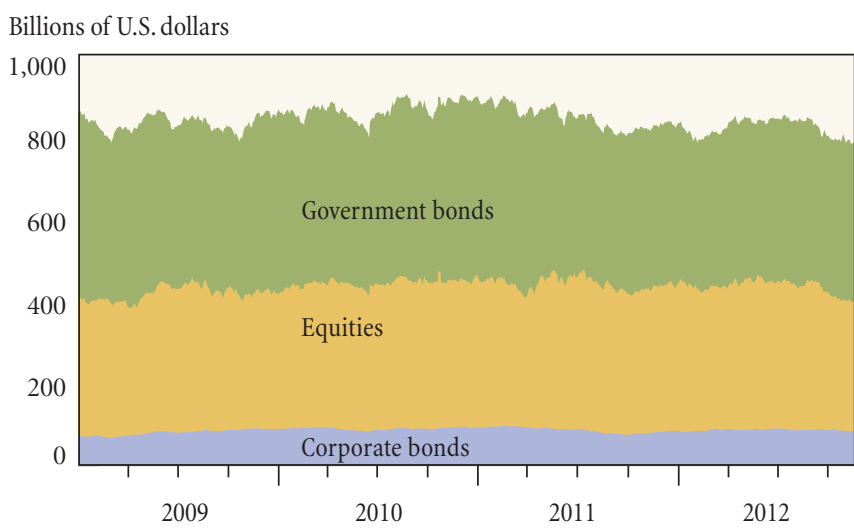

Source: Markit ${ }^{\mathrm{TM}}$ Group Limited 
surprisingly, the lender of the security typically pays interest to the borrower on the cash received as collateral. ${ }^{6}$ This interest is known as the rebate rate. The more desirable the securities being lent, the lower the rebate rate will be. For very scarce securities, rebate rates can be zero or negative.

The reinvestment return reflects net earnings from cash reinvestment. This second source of earnings is what distinguishes the securities-for-cash loan from other forms of securities lending. It can be viewed as a collateral or money market transaction with an embedded ancillary activity of cash reinvestment. In other words, it combines a funding market transaction with the distinct activity of cash reinvestment. ${ }^{7}$

Understanding the rebate rate in a securities-for-cash transaction is instructive for two reasons: 1) it may help identify whether the purpose of the transaction is to access the money market or the collateral market, and 2) it helps delineate how much of a transaction's return derives from collateral market intrinsic value or reinvestment return. Gross earnings that an agent and a beneficial owner share in a securities-for-cash transaction can be expressed as the following:

$$
\text { gross earnings }=\text { cash reinvestment rate }- \text { rebate rate }
$$

For the purposes of arbitrage, the rebate rate must be comparable to the rate paid on a repo collateralized by the same securities as those being lent in the securities-lending transaction. If these rates were not very close, one of the parties to the trade would find it beneficial to transact in the repo market instead. The risk potential associated with the cash reinvestment is distinct from the collateral or money market feature of the securities loan. As such, the rebate rate does not reflect cash reinvestment risk.

An implication of this relationship is that if the securities have no intrinsic value in the collateral market, then the rebate rate will be equal to the general level of money market interest rates. If, instead, the rebate rate is lower than the relevant general money market rate, then the rebate rate signals that the security being lent has intrinsic value in the collateral market and the transaction is motivated, at least in part, by the borrower's desire for a specific security. The level of the rebate rate in a securities loan provides the same price signal as the level of the repo rate in a repo transaction. ${ }^{8}$

\footnotetext{
${ }^{6}$ The interest rate paid by the security lender (cash receiver) is embedded in the gross earnings formula used to share transaction earnings between the agent and the beneficial owner: gross earnings $=$ cash reinvestment rate - rebate rate .

${ }^{7}$ In some cases, the purpose of the funding market transaction is primarily to access the collateral market. In other cases, however, the primary purpose may be to raise funds from the money market.

${ }^{8}$ See Keane (1996) for a discussion of how the repo rate signals whether the transaction is motivated by a desire to borrow money or a security. Also, see Duffie (1996) for a lengthier discussion of "special" repo transactions in the market for collateral.
}

The cash reinvestment rate is simply the gross return on the cash collateral reinvestment. Note that this return will depend on the risk and the illiquidity of the assets in which the cash is invested. Riskier and more illiquid assets will typically offer a higher potential yield. Comparing the cash reinvestment rate with prevailing money market rates of return offers some indication of the relative risk of the reinvestment activity.

In determining if the rebate rate of a securities loan reflects a transaction motivated by the desire to borrow money or the desire to borrow a security, it is important to be precise and compare the rebate rate to the appropriate money market rate based on the type of security lent. If the loan is a Treasury security, the appropriate rate for comparison is the Treasury general collateral rate. If mortgage-backed securities (MBS) are lent, the appropriate rate for comparison would be the MBS general collateral rate. ${ }^{9}$ If the rebate rate is equal to or above the relevant general collateral rate, then the transaction is motivated by the security lender's desire to borrow money rather than by the security borrower's demand for a security. Such a transaction is a "securities loan" in name only.

Information on the rebate rate along with the type of security lent would be sufficient, in many cases, to identify whether a particular securities-for-cash transaction is driven by pure yield-enhancement activity — an activity that falls broadly into the realm of shadow banking rather than a collateral market transaction. A securities-for-cash loan transaction would fall into the pure yield-enhancement category if the security lent has no specific value in collateral markets. Information on the cash reinvestment rate would also be useful because it could indicate the extent of risk in the cash reinvestment strategy.

Securities-Lending Returns versus Cash Reinvestment Returns The Markit reporting panel divides earnings from securitiesfor-cash loan transactions into two sources: 1) collateral market intrinsic value, and 2) net cash reinvestment returns. These are shown in Chart 2 across three security classifications: government securities, equities, and corporate bonds. Collateral market intrinsic value is labeled as "securities lending" and net cash reinvestment returns are "cash reinvestment."10

Over the past three years, loans of government securities, equities, and corporate bonds show varying contributions from these two earnings sources and some shifts in the relative contribution of each source over relatively short time

\footnotetext{
${ }^{9}$ Such precise interpretations of a security loan's rebate rate will not always apply. For instance, loans of equity securities are priced based on the scarcity of shares available to borrow relative to demand, independent of the general level of interest rates.

${ }^{10}$ The rebate rate can help define these return components: The spread between the rebate rate and the general collateral rate reflects the intrinsic collateral market value for loans of fixed-income securities, and the level of the rebate rate reflects the funding cost component of the reinvestment strategy. A portfolio manager might view the rebate rate level as a hurdle rate when investing the cash collateral.
} 


\section{Chart 2}

\section{Revenue Share from Securities Lending and Cash Reinvestment}
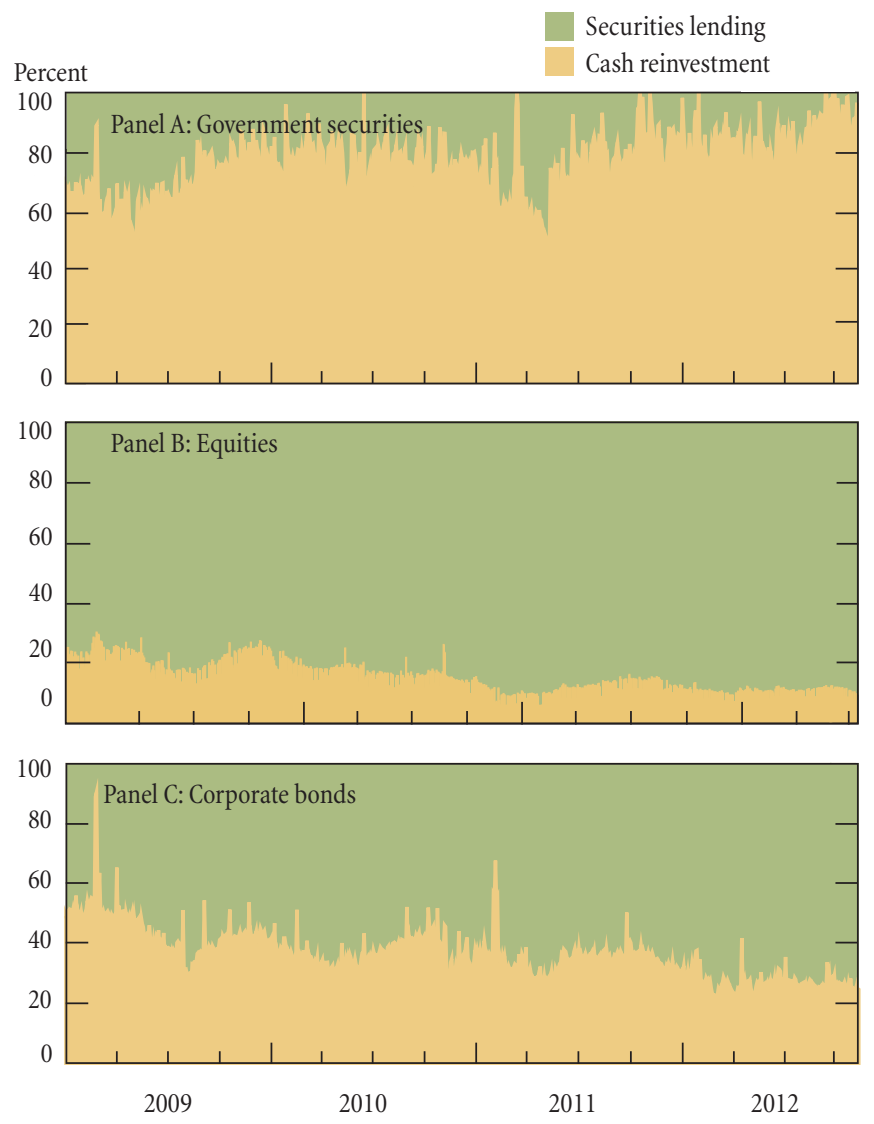

Sources: Markit ${ }^{\mathrm{TM}}$ Group Limited, author's calculations.

frames. The profitability of government security loans for this period relied mostly on reinvestment income rather than securities loan intrinsic value. Loans of equity securities show that the predominant earnings contribution was derived from collateral market demand or "collateral market intrinsic value." Revenue related to loans of corporate bonds reflects a variable pattern over recent years, moving from a greater contribution from reinvestment income to a higher contribution from collateral market intrinsic value.

\section{Risks Associated with Cash Reinvestment}

In a securities-for-cash loan transaction, the lending agent actively reinvests cash collateral in an effort to generate additional returns, which, if realized, are split between the agent and the beneficial owner. As already noted, the cash reinvestment activity is ancillary to the collateral market purpose of the securities loan transaction and is not strictly necessary for the functioning of collateral markets. Yet, in some cases, the acquisition of cash to fund reinvestment strategies becomes the primary or sole purpose of a securities loan transaction: The agent uses this short-term liability to fund a levered investment strategy, receiving cash in place of securities that are not in demand in the collateral market.
This action is potentially problematic because cash reinvestment can entail risks, described in more detail below. Also, it is important to recognize that such risks are absent from securities-lending transactions when the collateral is not cash.

The relative earnings data for securities-for-cash loans illustrate some of the concerns here. These data suggest, perhaps unexpectedly, that recent returns for loans of government securities against cash may have entailed greater embedded reinvestment risk than loans of corporate or equity securities, mainly because the primary source of returns was revenue from cash reinvestment. While the lack of transparency around the underlying assets held as temporary investments by lenders of government securities does not allow for a definitive conclusion, it suggests a need for more transparency around cash market reinvestment so that more reliable conclusions can be reached.

Although the financial literature suggests that securities lending can be a beneficial mechanism for financing short positions and facilitating hedging and price discovery, it is silent on the question of whether there is justification for securities loans used purely as a mechanism to raise short-term funds. Further research may be needed to determine whether such "in name only" securities loans serve a useful social need.

\section{Cash Reinvestment Practices}

Given that the beneficial owner owns the lent securities on an outright basis, the cash raised through a securities loan transaction and used by its agent is a source of leverage. The cash reinvestment can include maturity and/or liquidity transformation. As already mentioned, maturity transformation occurs if the maturity of the assets in which the cash has been reinvested exceeds the maturity of the security loan transaction. Most securities loans are "open," which could make their maturity as short as one business day. Liquidity transformation occurs if the time necessary to sell the securities exceeds the maturity of the loan. As such, cash reinvestment can be compared to a bank-like maturity transformation strategy, which falls under the realm of shadow banking. In addition, cash reinvestment can entail financial risk, because the value of the assets in which the cash is reinvested can fluctuate and may drop below the value of the cash that needs to be returned to the borrower of the securities.

The range of investment strategies is determined by the agent lenders' risk managers. Nevertheless, beneficial owners can impose contractual constraints on the range of assets a lending agent may purchase. Historically, however, the disclosure practices of agent lenders and the risk limits imposed by beneficial owners have been uneven, sometimes resulting in large unexpected losses for beneficial owners and eventual litigation. ${ }^{11}$

\footnotetext{
${ }^{11}$ See "Banks Shared Clients' Profits, but Not Losses," New York Times, October 18, 2010.
} 
An important consequence of making the main purpose of a securities loan the generation of cash in support of an aggressive reinvestment strategy is that the role of cash as collateral may be compromised. In other words, using the cash as a source of financial leverage means it no longer serves a purely riskmitigation function. ${ }^{12}$ Instead, the cash now becomes a source of liquidity and financial risk. If the cash is used to replace the value of a lent security, it can precipitate the untimely unwind of a related cash investment.

\section{Securities Lending in Name Only: The AIG Case}

While all available evidence suggests that the securities-for-cash loan transaction does not typically lead to market disruption or harmful unintended consequences, AIG's use of this transactional form provides a stark illustration of the potential for it to have significant consequences given the investment and incentive risks it can create. AIG used this form of securities lending as a mechanism for raising cash to support a yield-enhancement reinvestment strategy with no collateral market purpose, and such use was subject to the same run risk as exists in repo markets. ${ }^{13}$

In AIG's case, liquidity and financial risk related to cash reinvestment rose to a level that threatened the survival of the institution and financial stability more generally, ultimately leading to the creation of two emergency Federal Reserve facilities: the AIG Securities Borrowing Facility and Maiden Lane II LLC. ${ }^{14}$ AIG needed access to emergency liquidity because it used securities loans to fund investment in what proved to be illiquid residential MBS that were valued at deep discounts at the time its counterparties withdrew funding. ${ }^{15}$

Understandably, on the heels of these events came calls for greater transparency in securities lending. In particular, the AIG case seems to raise the question of whether greater transparency around cash reinvestment practices for this form of securities lending should include disclosures to regulators and cash providers in addition to beneficial owners. The potential for systemic risk that AIG's use of the transaction

\footnotetext{
${ }^{12}$ Common indemnification protections, wherein agents indemnify against loss related to nonreturn of the security lent, are consistent with freeing the cash from its role as collateral and allowing it to be used in an at-risk reinvestment strategy. For transactions without any or full indemnification, the role of cash as collateral is conflicted.

${ }^{13}$ See Gorton and Metrick (2012) for a discussion of run risk related to repo transactions.

${ }^{14}$ See http://www.federalreserve.gov/newsevents/reform_aig.htm for a description of credit extensions made by the Federal Reserve to AIG under the authority of section 13(3) of the Federal Reserve Act. These credit extensions provided liquidity support to AIG's securities-lending operation. The webpage cited here includes broad classification detail on the securities AIG pledged to the Federal Reserve under these two programs. At a high level, through these emergency liquidity facilities, the Federal Reserve provided AIG with approximately $\$ 20$ billion in liquidity support, secured by nearly $\$ 38$ billion in securities.

15 See the speech by Federal Reserve Governor Donald Kohn at http://www.federalreserve.gov/newsevents/testimony/kohn20090305a.htm.
}

demonstrated may raise the transparency bar given that these practices, when left unchecked, resulted in unintended systemic consequences.

\section{Agent Compensation Incentive Issues}

The agent's compensation is commonly a proportion of gains from the reinvestment of cash and collateral market value, but the agent faces no exposure if there are net losses. The fee split between agent and beneficial owner is subject to negotiation, but it is common for the beneficial owner to retain a high majority of income associated with cash reinvestment.

Recall that in a securities-for-cash loan transaction, the beneficial owner may have two potential sources of incremental return: the fee for the lent security and any return generated by reinvestment of the cash collateral. ${ }^{16}$ This second source of potential return is where misaligned incentive risk resides.

The fee-splitting arrangement creates risk-seeking incentives for securities-lending agents that are not unlike those of a hedge fund manager. Fee income is a direct function of investment returns, but there is no direct exposure to net losses. One might view the securities-lending agent's incentives as akin to a free long option position, in which securities-lending agents participate proportionally in higher cash reinvestment returns but are not exposed to net losses from this activity. As described in Merton (1973), the owner of a call option has an incentive to pursue a risk-seeking strategy because holding higher-volatility exposures increases the expected value of a long call-option position.

Anecdotal evidence suggests that excessive risk was a problem in the lead-up to the financial crisis. Such incentive issues appear to be generally well managed at present, but they nonetheless could contribute to financial instability through excessive maturity transformation, especially when the nature of reinvestment activity is opaque. This type of incentive issue is not present in other forms of the securities loan transaction or in repo transactions.

\section{Unlimited Range of Possible Reinvestment Strategies} In principle, beneficial owners can and should make sure that agent lenders, or even the owner's internal business functions that reinvest cash collateral, do not take risks that exceed the desired tolerance level. Before the financial crisis, some beneficial owners appear to have conducted little risk management, owing at least partly to limited visibility into investment practices.

Because most securities loans are "open" and therefore have an effective rolling overnight maturity profile, the lender of a security may have to return the cash collateral on very short notice. In normal times, this will typically occur when

\footnotetext{
${ }^{16}$ In the pure yield-enhancement case, a beneficial owner has only reinvestment returns as a potential source of return.
} 
Box 2

\section{Main Policy Issues for Securities Loans Collateralized by Cash}

\begin{abstract}
Indemnification
It is common for agents to offer beneficial owners indemnification for the replacement costs associated with nonreturn of a security. Nevertheless, understanding an agent's indemnification practices is critically important for beneficial owners, regulators, and cash providers. The riskiness of cash reinvestment must be weighed against the scope of indemnification. If agents invest in other than a risk-free overnight instrument, then the agent's indemnification must be strong. The reason is that when cash supports a levered purchase of a risky asset, it is no longer able to act as collateral because it cannot serve two purposes at once. Beneficial owners and cash providers should exercise extra diligence in overseeing investment practices if an agent does not offer any indemnification. Otherwise, they will have lent securities without a strong collateral arrangement. That is, use of the cash collateral may precipitate investment losses greater than the exposure created by nonreturn of the lent security.
\end{abstract}

\section{Visibility of Reinvestment Risk}

While uncommon, the AIG experience shows how overly aggressive use of cash generated from securities loans can contribute to financial instability. AIG's cash reinvestment in an enormous illiquid MBS portfolio was not transparent to its counterparties or to others in the market. When the financial crisis resulted in a general reduction in short-term funding, AIG had no recourse in public markets.

the borrower no longer needs the securities lent. In stressed times, however, it could occur because the borrower fears that the lender may default. The borrower's incentive to return the securities to protect itself from the loss of cash collateral will be particularly strong if the securities are general collateral and do not have a high economic value to the borrower. In that sense, funding obtained through loans of securities is subject to run risk, much like bank deposits are in a traditional bank run. In fact, the absence of any form of protection, such as deposit insurance, makes the run risk particularly acute.

If investment activity were limited to the money market instruments, the attendant risks would be more manageable because these assets are typically liquid and have a short maturity, which limits the potential for maturity or liquidity mismatch. But the risk increases when the cash is reinvested in less liquid instruments. The open-ended nature of cash reinvestment and the hedge-fund-like incentives of those investing the cash have, in some cases, resulted in cash reinvestment well beyond the relative safety of money market investments, stretching maturity and credit transformation to imprudent and unsustainable levels. Such extreme investment strategies in practice are not wholly surprising given the incentive structure in place for agents.

Risk-seeking incentives in agent compensation arrangements and the opaque nature of cash market reinvestment activities are an uneasy combination that did, in fact, contribute to

\section{Risk Oversight by Beneficial Owners}

Beneficial owners seem best served when they coordinate closely with agents and limit the scope of permissible reinvestment activities to a predetermined schedule of assets. This practice helps align incentives to limit the risk profile of yield-enhancement strategies pursued by the agent. In cases similar to AIG, in which the securities-lending agent was housed internally, such incentive alignment may fall to internal risk managers or to regulators. ${ }^{\text {a }}$

\section{Diligence by Cash Providers}

Cash providers should carefully monitor the securities-lending transaction as a credit extension when the intrinsic value of the collateral is not driving the transaction. A counterparty that extends large amounts of cash will want a good understanding of the reinvestment activity it supports. Admittedly, such diligence might prove difficult or impossible in practice as cash is fungible and cash borrowers (securities lenders) may have incentives to disclose credible but inaccurate descriptions of asset reinvestment parameters to counterparties. Future gains in transparency around reinvestment activity would make such diligence more attainable.

\footnotetext{
a The proposal to increase regulatory oversight through greater data transparency may address this gap.
}

systemic instability in 2008. The Financial Stability Board is advocating greater transparency of cash reinvestment activity, which seems a prudent course to follow. Increased transparency will give all market stakeholders (including regulators and the counterparties providing cash to securities lenders) greater ability to accurately assess the riskiness of the transaction.

Greater transparency may also act as a discipline on agents' risk taking in that overly aggressive strategies would be less likely to gain funding at the outset. Moreover, if there is a clearer understanding of cash reinvestment exposures, funding might be withdrawn before financial risk grows to unmanageable levels. Market participants might also consider new compensation arrangements to diminish risk-seeking incentives. One possible change in compensation would give agents a larger share of earnings in exchange for a proportional share of investment losses. Such changes in incentives could reinforce improved transparency initiatives already under discussion. (See Box 2 for a discussion of the main policy issues.)

\section{Conclusion}

While it might be tempting to suggest eliminating the lending of securities against cash collateral, such a policy response may be too extreme. First, some uses of the practice are benign. It does, for example, make it easier to intermediate between repo and securities-lending 
transactions in sourcing specific securities for collateral market transactions. ${ }^{17}$ Second, cash reinvestment activities are, for the most part, managed appropriately.

Nevertheless, search for yield can lead to investments of cash that result in dramatic maturity or credit transformation, sometimes both. The unlimited flexibility of the cash reinvestment option for the securities-for-cash loan transaction, combined with the incentives of agent compensation arrangements, suggests that scrutiny and understanding of cash reinvestment practices should move to the forefront of securities loan risk management-especially in light of the AIG experience, which showed that risk taking through cash reinvestment by even a single participant could have destabilizing effects.

Improved transparency practices in securities-lending transactions with a cash reinvestment can realign incentives and avert extreme and potentially destabilizing outcomes. These transparency improvements may come through both regulatory and market best-practice initiatives.

Market participants should consider both the social benefits of increased transparency and the need to refine standard agent compensation arrangements to limit the risk-seeking incentives of agents in the securities-for-cash

\footnotetext{
${ }^{17}$ Note, however, that such activity would result in no added investment income from cash reinvestment if the cash is used back-to-back with a repo transaction. That the industry carefully tracks investment income as a performance metric suggests that such benign use is not typical of this form of the securities loan transaction.
}

loan transaction. Such reflection seems prudent given recent experience and the existence of alternative transactional forms that appear less prone to unexpected outcomes. An increase in data transparency, in particular around cash reinvestment choices, seems likely to lower the possibility of runs and is a reasonable cost to bear if it mitigates the risk of financial system disruption.

\section{References}

Adrian, Tobias, Brian Begalle, Adam Copeland, and Antoine Martin. 2011. "Repo and Securities Lending." Federal Reserve Bank of New York Staff Reports, no. 529, December (revised January 2012).

Beltran, Daniel, Cecilia Caglio, Elizabeth Kiser, and Viktors Stebunovs. 2013. "Securities Lending and Systemic Risk: A Primer." Unpublished paper, Board of Governors of the Federal Reserve System.

Duffie, Darrell. 1996. “Special Repo Rates.” Journal of Finance 51, no. 2 (June): 493-526.

Federal Reserve Bank of New York. 2010. "Tri-party Repo Infrastructure Reform." White paper, May 17.

Financial Stability Board. 2012. "Securities Lending and Repos: Market Overview and Financial Stability Issues." Interim Report of the FSB Workstream on Securities Lending and Repos, April 27.

Gorton, Gary, and Andrew Metrick. 2012. "Securitized Banking and the Run on Repo.” Journal of Financial Economics 104, no. 3 (June): 425-51.

Keane, Frank. 1996. "Special Repo Rate Patterns for New Treasury Notes." Federal Reserve Bank of New York Current Issues in Economics and Finance 2, no. 10 (September).

Lipson, Paul, Bradley Sabel, and Frank Keane. 2012. "Securities Lending." Federal Reserve Bank of New York Staff Reports, no. 555, March.

Merton, Robert C. 1973. "Theory of Rational Option Pricing." Bell Journal of Economics and Management Science 4, no. 1 (spring): 141-83.

\section{ABOUT THE AUTHOR}

Frank M. Keane is a policy advisor and assistant vice president in the Markets Group.

The content co-editor of this article is Antoine Martin.

Current Issues in Economics and Finance is published by the Research and Statistics Group of the Federal Reserve Bank of New York. Linda Goldberg and Thomas Klitgaard are the editors of the series.

Editorial Staff: Valerie LaPorte, Mike De Mott, Michelle Bailer, Karen Carter, Anna Snider

Production: Jane Urry, Jessica lannuzzi, David Rosenberg

Back issues of Current Issues are available at http://www.newyorkfed.org/research/current_issues/.

The views expressed in this article are those of the author and do not necessarily reflect the position of the Federal Reserve Bank of New York or the Federal Reserve System. 